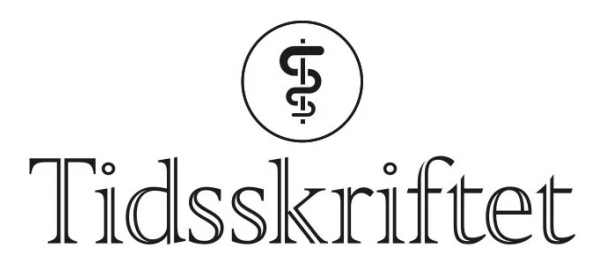

DEN NORSKE LEGEFORENING

\title{
Totalresistent tuberkulose?
}

KOMMENTAR

\section{ULF R. DAHLE}

Ulf R. Dahle (f. 1966) er dr.odont. og avdelingsdirektør ved Avdeling for næringsmiddelbårne infeksjoner, Divisjon for smittevern, Nasjonalt folkehelseinstitutt. Ingen oppgitte interessekonflikter.

Email: ulf.dahle@fhi.no

Divisjon for smittevern

Nasjonalt folkehelseinstitutt

Fra India er det nylig rapportert om tilfeller av totalresistent tuberkulose. Funnene er benektet av indiske myndigheter og ikke endelig bekreftet. Men det er ingen tvil om at dagens situasjon gir stor grunn til bekymring - er vi på vei inn i en æra der tuberkulose ikke lenger kan behandles?

Aminoglykosidet streptomycin revolusjonerte medisinen da Albert Schatz og Selman Waksman og deres medarbeidere i 1943 oppdaget at det kunne kurere tuberkulose (1). Streptomycin brukes ved en rekke andre infeksjoner også, men fikk enorm betydning $\mathrm{i}$ tuberkulosebehandlingen, da det endelig syntes som om denne sykdommens tusen års terrorregime kunne være ved veis ende. På samme tid kunne også Jørgen Lehmann og KarlGustav Rosdahl syntetisere paraaminosalisylsyre, som også var effektivt mot tuberkulose (2). Disse to oppdagelsene ga verden et lenge etterlengtet håp.

Legemidlene hadde ikke vært brukt lenge før man oppdaget at bakteriene utviklet toleranse for dem $(3,4$. .). Resistensproblemene kunne reduseres når preparatene ble benyttet i kombinasjon, men heller ikke på denne måten kunne resistens forhindres fullstendig. Gjennom 1950- og 6o-årene ble det fremstilt noen andre preparater som også var effektive mot M tuberculosis-infeksjon. Optimismen økte - tuberkulosen kunne kanskje utryddes?

\section{Totalresistent tuberkulose}

Det har likevel vist seg at etter oppdagelsen av isoniazid (1952), pyrazinamid (1954), etambutol (1962) og rifampicin (1963) er det ikke fremstilt andre legemidler som karakteriseres som førstelinjemedikamenter mot tuberkulose (5). Det er bekymringsfullt at $\mathrm{M}$ tuberculosis hele denne perioden har ervervet ytterligere resistens mot de få medikamentene som er tilgjengelige (므). I 199o-årene ble multiresistent tuberkulose 
(MDR-TB) en fryktet diagnose og en utfordring å behandle (7.). Siden 2005 har utvidet resistens (XDR-TB) overtatt rollen som «det verste tuberkulosescenario» (모). Dette kan nå være i ferd med å endres igjen.

Fra India ble det nylig rapportert om fire tilfeller av totalresistent tuberkulose. Bakterieisolatene var resistente mot alle førstelinjepreparatene (isoniazid, rifampicin, etambutol, pyrazinamid og streptomycin) og mot alle testede annenlinjepreparater (ofloksacin, moksifloksacin, kanamycin, amikacin, capreomycin, paraaminosalisylsyre og etionamid). Alle legemidlene ble testet ved hjelp av WHO-anbefalte konsentrasjoner og bruk av Mycobacterial Growth Indicator Tube 96o (MGIT - 96o). For noen av stoffene er resistensfunnene bekreftet genetisk hos tre av isolatene (9.).

\section{Politisk tåkelegging}

Slike rapporter kommer ikke uventet, og totalresistent tuberkulose har vært rapportert tidligere (무). Denne siste rapporten fra India har derimot skapt en annerledes uro enn man hadde forventet. Helsedepartementet i landet protesterer på rapporten fra Hindujasykehuset - de henviser til at begrepet «totalresistent tuberkulose» ikke er anerkjent av Verdens helseorganisasjon (WHO) og hevder at de nevnte tilfellene skal betraktes som XDR-TB. Samtidig understreker departementet at Hinduja-sykehuset ikke er akkreditert for resistensbestemmelse av annenlinjepreparater mot tuberkulose (111).

Det er kjent at indiske laboratorier er sparsomt utrustet, at behandlingsrutinene er ufullstendige, medikamentforsyningen uforutsigbar og at det indiske kontrollprogrammet mot tuberkulose trenger bedre økonomiske forutsetninger. Videre er det kjent at myndighetene trenger sterkere kontroll med det private helsevesen (12). Det er også underlig at funnene av totalresistente $\mathrm{M}$ tuberculosis-isolater ikke er bekreftet av et annet laboratorium. Likevel er det urovekkende at indiske helsemyndigheter søker å tåkelegge debatten knyttet til det enorme resistensproblemet India og verden står overfor. Man har sett det komme i 70 år og det er stor grunn til bekymring for at totalresistent tuberkulose kan bringe oss tilbake til en situasjon dominert av fortvilelse, sanatorier, håpløse sykeleier og alt det vi har lest om i bøker.

\section{Behov for internasjonal innsats}

Resistent tuberkulose skyldes feilaktig bruk av tuberkulosemedikamenter. Internasjonale retningslinjer, strategier og kampanjer har vektlagt dette i en årrekke. Nøkkelen for å forebygge resistent tuberkulose, MDR-TB og XDR-TB er å sikre at pasientene får tilgang til korrekt behandling med riktig kombinasjon av legemidler over lang nok tid. Dette bør gjøres under direkte observert behandling. Man kan ikke forebygge resistent tuberkulose ved å diskutere filologiske spørsmål og laboratoriers kvalifikasjoner. Det er uklart om totalresistent tuberkulose allerede har oppstått, men det er ingen tvil om at man er ganske nær og at den en dag vil bli en reell trussel. I Norge har vi allerede erfart tilfeller av tuberkulose som var resistent mot nesten alle kjente tuberkulosemedikamenter (13).

Hva gjør vi den dagen M tuberculosis igjen blir en infeksjon man ikke kan behandle?

Publisert først på nett 5.3. 2012 Podkast på www.tidsskriftet.no

\section{LITTERATUR}

1. Schatz A, Waksman SA. Strain specificity and production of antibiotic substances: IV. Variations among Actionomycetes, with special reference to Actinomyces griseus. Proc Natl Acad Sci USA 1945; 31:129-37. [PubMed] [CrossRef]

2. Lehmann J. Para-aminosalicylic acid in the treatment of tuberculosis. Lancet 1946;1: 15. 
3. Feldman WH, Karlson AG, Hinshaw HC. Streptomycin-resistant tubercle bacilli; effect of resistance on therapeutic results. Am J Pathol 1947; 23: 874. [PubMed]

4. Graessle OE, Pietrowski JJ. The in vitro effect of para-aminosalisylic acid (PAS) in preventing acquired resistance to streptomycin by mycobacterium tuberculosis. J Bacteriol 1949; 57: 459-64.

5. Koul A, Arnoult E, Lounis N et al. The challenge of new drug discovery for tuberculosis. Nature 2011; 469:483-9o. [PubMed] [CrossRef]

6. Steiner M, Cosio A. Primary tuberculosis in children. 1. Incidence of primary drug-resistant disease in 332 children observed between the years 1961 and 1964 at the Kings County Medical Center of Brooklyn. N Engl J Med 1966; 274: 755-9. [PubMed] [CrossRef]

7. From the Centers for Disease Control. Outbreak of multidrug-resistant tuberculosis - Texas, California, and Pennsylvania. JAMA 1990; 264: 173-4. [PubMed] [CrossRef]

8. Raviglione MC, Smith IM. XDR tuberculosis - implications for global public health. N Engl J Med 2007; 356: 656-9. [PubMed] [CrossRef]

9. Udwadia ZF, Amale RA, Ajbani KK et al. Totally drug-resistant tuberculosis in India. Clin Infect Dis 2012; 54: 579-81. [PubMed] [CrossRef]

10. Velayati AA, Masjedi MR, Farnia P et al. Emergence of new forms of totally drug-resistant tuberculosis bacilli: super extensively drug-resistant tuberculosis or totally drug-resistant strains in Iran. Chest 2009; 136: 420-5. [PubMed] [CrossRef]

11. Mudur G. Indian health ministry challenges report of totally drug resistant tuberculosis. BMJ 2012; 344: e702. [PubMed] [CrossRef]

12. Mudur G. Indian doctors demand better second line treatment for patients with drug resistant tuberculosis. BMJ 2009; 338: b8. [PubMed] [CrossRef]

13. von der Lippe B, Sandven P, Brubakk O. Efficacy and safety of linezolid in multidrug resistant tuberculosis (MDR-TB) - a report of ten cases. J Infect 2006; 52: 92-6. [PubMed] [CrossRef]

Publisert: 27. mars 2012. Tidsskr Nor Legeforen. DOI: 10.4045/tidsskr.12.0168

Mottatt 3.2. 2012 og godkjent 16.2. 2012. Medisinsk redaktør Anne Kveim Lie.

(C) Tidsskrift for Den norske legeforening 2023. Lastet ned fra tidsskriftet.no 26. april 2023. 